University of Tulsa College of Law

TU Law Digital Commons

Articles, Chapters in Books and Other Contributions to Scholarly Works

1989

\title{
Teleology, Monocausality, and Marriage in Ulysses
}

Robert Spoo

Follow this and additional works at: http://digitalcommons.law.utulsa.edu/fac_pub

Part of the English Language and Literature Commons

\section{Recommended Citation}

English Literary History 56 (1989): 439-462.

This Article is brought to you for free and open access by TU Law Digital Commons. It has been accepted for inclusion in Articles, Chapters in Books and Other Contributions to Scholarly Works by an authorized administrator of TU Law Digital Commons. For more information, please contact daniel-bell@utulsa.edu. 


\section{ELH, 00650 (1t85)}

\section{TELEOLOGY, MONOCAUSALITY, AND MARRIAGE IN ULYSSES}

BY ROBERT SPOO

Preformationism, teleologism, reduction of force, value and duration-these are as one with geometrism, creating structure.

-Jacques Derrida, "Force and Signification"

Permanence means paralysis and death. Only in movement, with all its pain, is life.

\section{- Jacob Burckhardt, "On Fortune and Misfortune in History"}

In Writing Degree Zero, Roland Barthes describes the French preterite as "the ideal instrument for every construction of a world," and notes that "it is the unreal time of cosmogonies, myths, History and Novels." Barthes finds this verb form-the "operative sign whereby the narrator reduces the exploded reality to a slim and pure logos"- to be the special signature of historical and fictional narratives:

When the historian states that the duc de Guise died on December 23rd, 1588, or when the novelist relates that the Marchioness went out at five o'clock, such actions emerge from a past without substance; purged of the uncertainty of experience, they have the stability and outline of an algebra, they are a recollection, the interest of which far surpasses its duration. ${ }^{2}$

The "sole function" of the preterite, whether it is used by the historian or the novelist, is "to unite as rapidly as possible a cause and an end." It is the smallest unit, in other words, of teleology, that governing structure and ruling passion "common to the Novel and narrated History."3

Since Ulysses is a novel much concerned with history and the ways in which history is formulated, it is not surprising that it should examine teleological assumptions of all kinds. Joyce would undoubtedly have agreed with Jacques Derrida when the latter declared, "What we must be wary of, I repeat, is the metaphysical concept of history ... history as the history of meaning ... devel- 
oping itself, producing itself, fulfilling itself. And doing so linearly ... in a straight or circular line."4 As early as 1902, in his essay on the Irish poet James Clarence Mangan, Joyce declared himself an enemy of historical teleology. He considered poetry to be "at war with its age, so it makes no account of history, which is fabled by the daughters of memory." 5 This last phrase is familiar as Stephen Dedalus's characterization of the dry-as-dust history he teaches at the Dalkey school in "Nestor," the episode that formally broaches the issue of teleology. "History encloses [Mangan] so straitly," the essay continues, "that even his fiery moments do not set him free from it" ( $C W, 81)$. The same could be said of Stephen, who suffers from the "nightmare of history." "No doubt," Joyce remarks in the same piece, "they are only men of letters who insist on the succession of the ages[;] and history or the denial of reality, for they are two names for the one thing, may be said to be that which deceives the whole world" $(C W, 81)$. The young Joyce, like his fictional counterpart, distrusted the dominant nineteenth-century conception of history as "the succession of the ages," what Derrida describes as "history ... developing itself, producing itself, fulfilling itself ... linearly." And Joyce's phrase "history or the denial of reality" hints at assumptions similar to those in Barthes's critique of the teleological preterite, "whereby the narrator reduces the exploded reality to a slim and pure logos."

When Joyce revised the Mangan essay for a lecture in 1907, he expanded his attack on historical misconceptions, or what he now called "idols of the market place." These he listed as "the succession of the ages, the spirit of the age, the mission of the race" $(C W$, 185). He had not forgotten these "idols" when he came to compose "Nestor" a decade later, for they are succinctly contained in the schoolmaster Deasy's grandiose remark that "All human history moves towards one great goal, the manifestation of God" (2.380-81; $34.27-28) .{ }^{6}$ In one of his schemata for Ulysses, Joyce designated "History" as the "Science, Art" of "Nestor," and it is possible that he was remembering his old formula "history or the denial of reality." In a sense, nightmares deny reality too, and it is on the field of history and in the cause of reality that Stephen does battle with the nightmarish Deasy, enacting what Joyce in the 1907 lecture described as "the poet's central effort ... to free himself from the unfortunate influence of these idols that corrupt him from without and within" $(C W, 185){ }^{7}$ 
This essay examines the ways in which Joyce's novel seriously (and comically) questions teleology and its near kin, monocausality (or origin as full presence), as they operate in fictional and historical narrative, and especially as they reveal themselves in the (hi)story of June 16, 1904. We shall see, moreover, how this nexus of history and story is reflected in a curious marriage motif that runs through Ulysses, suggesting, among other things, the ways in which this "ultimate novel" liberates itself from the genre's traditional dependence on the bourgeois marriage ethos for the goal or telos of narrative development.

\section{THE GOAL OF HISTORY AND STORY}

With Deasy's “manifestation of God" pronouncement, teleology makes its grand thematic entrance in Ulysses. This type of history has been variously called providentialist, developmental, Whig, and Hegelian. Of Hegel's conception of history Ernst Cassirer writes, "Even previous philosophic or theological thinkers as for instance St. Augustine, Vico, or Herder had spoken of history as a divine revelation. But in the Hegelian system history is no mere appearance of God, but his reality: God not only 'has' history, he is history." 8 Deasy's "ideology of progress" is an impoverished version of this philosophical system, which is, as Rudolf Haym writes, "the frightful doctrine which canonizes the subsisting as such."9 Deasy, too, insists on the rightness of what is, since it is through the subsisting - "all human history"-that God manifests Himself. In such a view, history becomes split, as R. G. Collingwood says, into "the abstract law and the mere fact." ${ }^{10}$ It is this abstracting of history that allows Deasy to speak so recklessly of the "facts" from his Orangeman's point of view. "You fenians forget some things," he tells Stephen after grossly misrepresenting the history of the Orange Lodges and the persecution of the Roman Catholics at the hands of the Protestants $(2.268-72 ; 31.17-22)$. According to Deasy, history's nightmares are merely phases of God's dream of Himself. This kind of history, moving "towards one great goal," is like the mathematical figures Stephen peruses in his student's copybook of "Sums": "Across the page the symbols moved in grave morrice, in the mummery of their letters" (2.155-56; 28.11-12). Compare this to Barthes's claim in his discussion of the preterite that structured, teleologized histories reflect "the stability and outline of an algebra." 
Stephen, for whom the totalization of history is an aspect of the nightmare from which he is trying to awake, resists Deasy's providentialist views:

Stephen jerked his thumb towards the window, saying: -That is God. Hooray! Ay! Whrrwhee!

-What? Mr Deasy asked.

-A shout in the street, Stephen answered, shrugging his shoulders. $(2.382-86 ; 34.29-34)$

Stephen's scholastic mind cannot resist completing the syllogism for which Deasy has unwittingly provided the first term: One, history is the manifestation of God. Two, a shout in the street is part of history. Three, therefore, a shout in the street is a manifestation of God. By implication, Stephen is contending that religious persecution (carried out by the ancestors of the well-to-do Protestant boys who attend the Dalkey school, and symbolically reenacted in the hockey game Stephen mentally likens to warfare) must also be part of God's self-exfoliation in history. But he is also suggesting in this deflation of Deasy's God that if meaning is to be found anywhere in history, it will be in the sheer randomness, the disjecta membra, of a day like this June day, even in an otherwise unarresting shout in the street. Not Deasy's "one great goal" but the random, insignificant goals of the schoolboys are the real data of history, and these hold the potential for alternative visions and meanings. ${ }^{11}$

Karl Popper notes that "all theistic interpretation of history attempts to see in history as it is recorded, i.e. in the history of power, and in historical success, the manifestation of God's will."12 Popper denounces this as "moral futurism," and claims that to "maintain that God reveals Himself in what is usually called 'history,' in the history of international crime and of mass murder, is indeed blasphemy." Stephen's reaction conceals a similar feeling of outrage, and his remark about a shout in the street shows him in accord with a further observation of Popper's:

The life of the forgotten, of the unknown individual man; his sorrows and his joys, his suffering and death, this is the real content of human experience down the ages. If that could be told by history, then I should certainly not say that it is blasphemy to see the finger of God in it. But such a history does not and cannot exist; and all the history which exists, our history of the Great and the Powerful, is at best a shallow comedy; it is the opera buffa played by the powers behind reality (comparable to Hom- 
er's opera buffa of the Olympian powers behind the scene of human struggles). ${ }^{13}$

More thoroughly even than Joyce's earlier fiction, Ulysses explores the random goals or teloi of history, and it does this through the story of "an unknown individual man" named Leopold Bloom: Joyce, like Popper, had come to feel that such a story was "the real content of human experience down the ages." 14 Ulysses is "Homer's opera buffa" with the gods removed, or what Joseph Conrad referred to as an "obscure 'Odyssey." "15

History and story gradually become indistinguishable in Ulysses: what Stephen implies in his enigmatic remarks to Deasy is realized two episodes later in the commencement of Bloom's day. That Bloom personally exemplifies this theme of anti-teleology is suggested by some seemingly random remarks of Stephen's in "Circe," just after the announcement that "Jewgreek is greekjew. Extremes meet": "What went forth to the ends of the world to traverse not itself, God, the sun, Shakespeare, a commercial traveller, having itself traversed in reality itself becomes that self. Wait a moment. Wait a second. Damn that fellow's noise in the street" (15.2117-20; 505.1-6). Stephen is referring literally to a gramophone blaring "The Holy City," but the text seems more interested in the associative cluster that throws together a "commercial traveller" and a "noise in the street."

The self traversing itself in order to become itself partly alludes to the Aristotelian notion of entelechy that Stephen explicitly contemplates in "Scylla and Charybdis" (9.208; 189.39) and in "Nestor," where he defines history as the actualizing of potentials (2.49-52; 25.16-19). "Entelechy" and "teleology" share the Greek root telos, which means end or perfection, but there is a world of difference between entelechial self-realization and teleological subordination of all entities to a single end or purpose. Kenneth Burke says of entelechy that

the kind of purpose [Aristotle] assigned to natural entities was hardly purpose in the Providential sense of the term. Though all motion and action are ultimately guided by a desire for the perfection of God, each kind of thing is conceived as striving to be perfectly the kind of thing it is. Teleology as thus modified allowed for much purely inductive study of genera and species. ${ }^{16}$

Ulysses is founded on an Aristotelian commitment to individual entities, a commitment that also helped inspire Joyce to treat mid- 
dle- and lower-class subjects and the seemingly negligible minutiae of the city. For if all things seek perfection, then all things are in some sense good, a generalization that resembles Augustine's doctrine of the good as Stephen recalls it in "Aeolus": "those things are good which yet are corrupted" (7.842-43; 142.21-22). Derrida takes Augustine's concept of "deficiency" even further, declaring the so-called deficient "evil" to be a positive element in structures. "The pathological itself," he says, "is not the simple absence of structure. It is organized. It cannot be understood as the deficiency, defect, or decomposition of a beautiful, ideal totality. It is not the simple undoing of telos" (WD, 26).

Behind Stephen's embracing of Aristotelian entelechy is a distrust of the totalizing tendencies of Platonism. This is especially clear in "Scylla and Charybdis," where he confronts the Dublin Platonists, John Eglinton and AE, who desire in art only "ideas, formless spiritual essences" and have no patience with "clergymen's discussions of the historicity of Jesus" (9.48-49; 185.13-14). In a series of associations linking Deasy to these Platonists, Stephen pits entelechy against teleology: "Streams of tendency and eons they worship. God: noise in the street: very peripatetic.... Hold to the now, the here, through which all future plunges to the past" (9.85-89; 186.14-20). And when Eglinton would reduce the historical Ann Hathaway to someone who "died, for literature at least, before she was born," Stephen angrily retorts, "She died ... sixtyseven years after she was born" (9.216-18; 190.6-9). He will not allow her to be reduced "to the inconsequentiality of accident or dross," as Derrida claims happens at the hands of "ultrastructuralists" to "everthing not intelligible in the light of a "preestablished' teleological framework" (WD, 25). Stephen will no more let the empirical, historical, entelechial Ann Hathaway be forgotten than Joyce would allow June 16, 1904, to fade into impalpability. Here Stephen's and Joyce's projects converge, for they reveal the same desire to preserve what Deasy and Eglinton regard as outside their systems and so dispensable. Eglinton is content, Stephen thinks, to reduce history to mere abstraction: "Here he ponders things that were not: what Caesar would have lived to do had he believed the soothsayer: what might have been: possibilities of the possible as possible: things not known: what name Achilles bore when he lived among women" $(9.348-51 ; 193.32-36){ }^{17}$

Parodies of Deasy's providentialist views emerge again and again in the text. In "Proteus"- the episode that in some sense returns 
the historical petrifactions of "Nestor" to their origin in the molten unpredictability of language-words themselves mock the notion of history as a rational, continuous manifestation of God. For what develops and exfoliates in this episode is not a unified, univocal vision of reality, but the play of language itself, the sources and resources of our own system-building. Stephen watches a dog nosing about the bloated carcass of another canine: "Dogskull, dogsniff, eyes on the ground, moves to one great goal" (3.350-51; 46.29-30). This transmogrifying of Deasy's doctrine involves the familiar God/dog flip-flop which T. S. Eliot also played on in The Waste Land (" 'O keep the Dog far hence, that's friend to men, / Or with his nails he'll dig it up again!' "). ${ }^{18}$ Here Stephen transposes the progressive manifestation of God into the merely successive manifestations of "dog," for the dog in this episode becomes by turns a horse, hare, buck, bear, wolf, calf-and ends up muzzle to muzzle with the carcass of a brother, death being the goal of its live sniffing. ${ }^{19}$

Towards the end of "Proteus" Stephen broods on another corpse, this time of an imagined drowned man, and creates for it a fanciful ecological career: "God becomes man becomes fish becomes barnacle goose becomes featherbed mountain" (3.477-79; 50.13-14). Developmental history is travestied once again here: progression gives way to succession (one damned thing after another, like shouts in the street, what Stephen might call "the Nacheinander" [3.12-13; 37.14]). Or to put it another way, verbal parataxis supplants historiographical hypotaxis. Moreover, "God becomes man" perversely reverses the "manifestation of God," thus preparing the way for Bloom, the antihero of a novel stubbornly resistant to the teleological patterns and closures typical of its genre. "Mr Leopold Bloom" enters the story immediately after the conclusion of "Proteus," almost as though he were one more avatar of the mutable canine: a shout in the street that was recently a bark on the beach. Proteus, not Hegel, presides over Joyce's fictive enterprise. If the story of Ulysses moves towards any goal, it is the manifestation of the god of change, one of whose guises appears to be a Protestant Irish Jew who sometimes resembles an ancient Greek.

History moves in this novel, but it would be hard to say in which direction. In "Wandering Rocks" we learn that "H. E. L. Y'S [sandwich-board men] filed ... tallwhitehatted, past Tangier lane, plodding towards their goal" (10.310-11; 227.23-24). But this "goal" is specified only as "between Monypeny's corner and the 
slab where Wolfe Tone's statue was not." Here the uncompleted statue of a famous Irish rebel suggests that there is always a gap in history precisely where totality of structure is most desired. Next we learn that the sandwich-boards "eeled themselves turning H. E. L. Y'S and plodded back as they had come" (10.377-79; $229.20-23) .^{20}$ This tedious retracing of the route comically subverts notions of linearity and may even gesture towards the cyclical preoccupations of the latter part of Ulysses and Finnegans Wake.

Stories with a point are as disagreeable to Stephen as histories with a goal, as is evident in his Parable of the Plums in "Aeolus." He perplexes his students at the Dalkey school with a conundrum about a "disappointed bridge" $(2.39 ; 25.4)$, and his equivocal fox riddle is a very different kind of pleasantry from Deasy's heavyhanded squib about Jews at the end of "Nestor": Deasy's story, like his history, has a cruel telos; Stephen's, typically, seems to be without a point. ${ }^{21}$ Late in the novel, Stephen asks Bloom to "oblige me by taking away that knife. I can't look at the point of it. It reminds me of Roman history" (16.815-16; 635.24-26). A connection between histories and stories is implied here, since Stephen has just heard the sailor Murphy's yarn about "a man killed in Trieste by an Italian chap. Knife in his back" (16.576; 628.33-34). This seems to be a pointless tale (like all of Murphy's stories), but it has a point that transcends its context: "Fellow hid behind a door, come up behind him. Like that. Prepare to meet your God, says he. Chuk! It went into his back up to the butt" (Joyce's italics; 16.580-82; $628.39-41$ ). Murphy's story curiously embodies Deasy's view of history moving towards the manifestation of God ("Prepare to meet your God"), along with that aspect of providentialism which condones the cruelties of history (one of Stephen's nightmare images in "Nestor" is relevant here: "Had . . Julius Caesar not been knifed to death" [2.48-49;25.14-15]).

Ulysses itself resists the culmination and closure of the traditional novel. One critic observes that "incomplete form characterizes much in the lives of the characters, it is a strategy of the text and demands the reader's supplementation," while another notes that Joyce consistently used structural techniques that are "enigmatic or open-ended, [an] example of incomplete form." 22 The principle of anti-teleology is realized in the structural openness of Joyce's novel, especially in the final episodes, which seem to court the possibility of closure and achieved teloi only to refuse in the last 
analysis to grant those satisfactions: Stephen and Bloom are "united" in only a qualified way; and Bloom's Odyssean return is to an altered domestic world that puts into question any easy dialectic of sundering/reconciliation.

Like Stephen's mysterious stories, the progression of styles and episodes in Ulysses shuns a discernible goal, appearing rather to be as spontaneous as history itself; and from what we know of Joyce's compositional procedure-that of adopting and abandoning styles-he was often as surprised as the reader by the methods he found himself using. Karen Lawrence has shown how Ulysses makes and then breaks stylistic contracts with the reader, so that even the initial "signature" style appears, in the light of the later experiments, to be no more or less authentic than any other style in the book. ${ }^{23}$ A "developmental" reading of Ulysses might regard "Ithaca," for instance, as the stylistic telos of the novel inasmuch as it reflects the "enlightened" nineteenth-century admiration for scientific explanations. But "Ithaca" is only one style among many styles, the last (barring Molly's monologue) among equals, and Joyce would never have assented to Auguste Comte's idea of Weltanschauungen passing from the theological to the philosophical and coming to rest in the scientific.

Could "Penelope" be the telos of Ulysses, that towards which all the styles move ineluctably? John Paul Riquelme says that the "final style, the end of wandering, in Ulysses is also the end of writing as its teleology: to present as style what no style can actually present." ${ }^{24}$ Though he is right, his terminology is misleading, for he has had recourse to a critical tradition that sees Molly's monologue in teleological terms. "Penelope" is not a telos precisely because it is not, as Riquelme suggests, a style, not in the sense that "Sirens" is, for example. ${ }^{25}$ For as Riquelme says, "The substance of ["Penelope"] is and will remain beyond the horizon of writing and of reading, always in the realm of the yet-to-be-written, the yetto-be-formulated, because it is inaccessible to writing." ${ }^{26}$ Molly's monologue does not gesture towards teleology as an ultimate, allinclusive structure. Rather, it intimates a ground from which linguistic forms emerge as meaning is discovered and isolated. "Penelope" is mimetic (as "Eumaeus," for instance, is not) of what Derrida calls "force," "becoming," "duration," that which transcends and exceeds structures and structuring: "The meaning of becoming and of force, by virtue of their pure, intrinsic character- 
istics, is the repose of the beginning and the end.... Within this peace and repose the character of becoming and of force is disturbed by meaning itself" (WD, 26).

In Molly's repose reside the beginning and end of Ulysses, as of all language and structure. But ground is not telos. "If there are structures," Derrida continues, "they are possible only on the basis of the fundamental structure which permits totality to open and overflow itself such that it takes on meaning by anticipating a telos which here must be understood in its most indeterminate form." "Penelope" can do no more than hint at this "fundamental structure" underlying all structures, and such a ground, in any event, cannot be linked causally, in terms of teleology or simple monocausality, to these structures. Monocausality, closely tied to teleology, represents another aspect of the history/story nexus in Ulysses, and it is to this concept that we now turn.

\section{ORIGIN AND CAUSATION}

Monocausality is a term for the reduction of causal complexity to a single cause or group of causes so simplistic as to be perniciously misleading. ${ }^{27}$ This simplified causality then becomes an origin that hopes to transform any number of disparate, opaque events into effortless, transparent "effects." Monocause and telos resemble each other to the extent that both are exhaustive determining structures (so that, for example, Thomistic theology can consider God to be the First Cause by virtue of His being the Final Cause); and they are both supremely indifferent to the variety and complexity of the particulars over which they preside. Michael Ryan defines monocausality as the "limitation of causality to the presence of an observable event," and, as his deconstructive terminology suggests, the monocause is in reality an absence that attempts to avoid or deny the differential textures that history weaves and unweaves. ${ }^{28}$ Kenneth Burke might call this avoidance a resort to "efficiency," a paring down of complexity to a manageable, winsome structure. ${ }^{29}$ When Leopold Bloom thinks, "Peace and war depend on some fellow's digestion" (8.752-53; 172.2-3), he is savoring the efficiency of a monocause.

"Nestor" contains two striking examples of monocausality, both of which proceed, as might be expected, from the mouth of Garrett Deasy. The first is his claim that "England is in the hands of the jews. In all the highest places: her finance, her press. And they are the signs of a nation's decay. ... As sure as we are standing here the 
jew merchants are already at their work of destruction. Old England is dying" (2.346-51; 33.28-34). Deasy's rhetoric is subtle; it vacillates between citing the Jews as the self-evident cause of England's troubles and regarding them as a mere symptom ("they are the signs of a nation's decay"). Since "nation" universalizes Deasy's complaint, Ireland (though she never let the Jews in, according to his parting crack) is also in danger of being corrupted. Deasy is not Stephen's first exposure to anti-Semitism this day. There is also Haines in "Telemachus": "I don't want to see my country fall into the hands of German jews either. That's our national problem, I'm afraid, just now" (1.666-68; 21.20-22).

Stephen contradicts Deasy on this matter in two ways. First, he silently recalls the eager brokers in front of the Paris Stock Exchange and is reminded of the historical persecution of the Jews: "Their eyes knew their years of wandering and, patient, knew the dishonours of their flesh" $(2.371-72 ; 34.15-16)$. Second, he alters the stress of Deasy's monocausal "jew merchants" to "jew merchants": "A merchant ... is one who buys cheap and sells dear, jew or gentile, is he not?" $(2.359-60 ; 34.1-2)$. The same rebuttal occurs to Stephen after Haines's remark about Jews in the first episode, though there it is merely implied by something Stephen observes: "Two men stood at the verge of the cliff, watching: businessman, boatman" (my italics, 1.669-70; 21.23-24). Stephen's skeptical mind will not let these historical simplifications go unchallenged, and, on the broader level of story, Ulysses develops and amplifies this skepticism by adducing Leopold Bloom, neither Jew nor Gentile by strict definition, nor even a merchant with influence in "all the highest places" (despite rumors of his association with Arthur Griffith). He has singular difficulty in two areas of public life that Deasy alleges to be contaminated by Jews: finance and the press. In fact, a good part of his day is spent performing charity for the Dignam family.

Mr. Deasy also complains to Stephen that

A woman brought sin into the world. For a woman who was no better than she should be, Helen, the runaway wife of Menelaus, ten years the Greeks made war on Troy. A faithless wife first brought the strangers to our shore here, MacMurrough's wife and her leman, O'Rourke, prince of Breffni. A woman too brought Parnell low. (2.390-94; 34.40-35.5)

Woman as monocause of all subsequent woes is a major theme in Ulysses. ${ }^{30}$ Stephen's Hamlet theory places Ann Hathaway at the 
origin of Shakespeare's personal anguish and his art: "He was overborne in a cornfield first," Stephen says, "and he will never be a victor in his own eyes after. . . No later undoing will undo the first undoing" (9.456-59; 196.26-31). The language of Stephen's theory is so reductive at times as to begin to modulate into an irony that questions these propositions, as when he equates Shakespeare's art with his alleged sexual wound: “The greyeyed goddess who bends over the boy Adonis . . . is a boldfaced Stratford wench who tumbles in a cornfield a lover younger than herself" (9.258-60; 191.15-18). Stephen's theory owes partly to his own need for a woman who will help him realize his art ("Ay, meacock. Who will woo you?" [9.938; 210.17-18]), and to his conviction, gradually evolved in A Portrait, that only by encountering the fallen, sinful world of experience (where women figure centrally) can the artist forge his soul and his art. But Stephen's theory ultimately cannot reduce woman to simple origin and cause, for the view he holds of genius complicates this neat, linear conception: "A man of genius makes no mistakes," Stephen says of Shakespeare. "His errors are volitional and are the portals of discovery" (9.228-29; 190.21-23). Shakespeare's own drive towards entelechy, towards realization of self and art, was as important as the wound inflicted by Ann Hathaway. Causality emerges as cooperative and complex, complex in the way Shakespeare's own works are complex.

Nor can the origin of Socratic maieusis be efficiently traced to the midwifery practiced by Socrates' mother, even though Stephen asserts playfully that Socrates learned from her "how to bring thoughts into the world" $(9.235-36 ; 190.29-30)$. The phrase recalls Deasy's "a woman brought sin into the world," and we recognize in the obstetric image the essential ambiguity of all causal attribution: children are the products of plural and cooperative causation, not of parthenogenesis. The patriarchal orotundity of Deasy's remarks about women is undermined by the maternal imagery he must resort to (the verb "brought" occurs twice more in the passage in question). It is precisely when his language would bury the individuality of women, repress their reality while yet locating them at the origin of evil as full presence, that the plurality of causation irrupts within the intersection of male names and images of birth: history, whether a nightmare or an Eden, is produced by men and women in strife and cooperation, though sexist historiography of the Deasy variety would obscure these complexities. 
Ulysses subverts woman-as-monocause in other ways. In "Aeolus," when Stephen is told that Deasy's wife is domineering, he mentally parodies the old man's theory about women-"A woman brought sin into the world" $(7.536 ; 132.26)$-comically implying that the monocause of Deasy's wisdom is Mrs. Deasy herself. And much later in the book, Bloom, feeling pity for the shabby whore who peeks into the cabman's shelter, says, "Of course I suppose some man is ultimately responsible for her condition" (16.731-32; 633.5-6). This reversal of Deasy's position is reinforced at once by Stephen's allusion to the Deasy interview: "She is a bad merchant. She buys dear and sells cheap" (16.738; 633.12-13).

Ann Hathaway is not the only woman Stephen sees as a threat to the male artist. May Dedalus, or rather her ghost, also appears as a menacing figure, and since this revenant is in some respects an embodiment of history, it is associated with Stephen's nightmare of history. ${ }^{31}$ Representing Church, nation, and family, the ghost figures the history that oppresses Stephen; it is the mère that comes in the night. But precisely because its signification is multiple and ambiguous (it is Church and nation and family, as well as Stephen's personal guilt), its figural status can never project history itself as a monocause. ${ }^{32}$ It cannot lend support to Haines's "it seems history is to blame" $(1.649 ; 20.40)$, but can only suggest how that formulation, like all claims about history and causality, is metaphorical, reductive, and provisional. Once the ghost is seen to be a metaphor, its univocity is rendered equivocal, its origin as presence deferred.

"A woman brought sin into the world. . . A woman too brought Parnell low." The theme of the treacherous woman as monocause resounds throughout Ulysses, but nowhere more importantly than in the question of Molly's adultery and its effect on Bloom. Is Molly the sole cause of the Blooms' marital difficulties? One of the things Bloom comes to terms with in the course of the day is his share of the responsibility for the sundering of their relations. The Junius style in "Oxen of the Sun" reflects Bloom's growing selfknowledge; "Unhappy woman, she [Molly] has been too long and too persistently denied her legitimate prerogative to listen to his objurgations with any other feeling than the derision of the desperate" (14.918-20; 409.20-23). Like all the parodies and styles in Ulysses, this one makes a 'thorough' presentation of the case, yet it also suggests quite seriously that simple causality will not do here. A large-scale deconstruction of causality in the Boylan/Molly affair is undertaken in "Ithaca," where Bloom's progress from envy 
and jealousy to abnegation and equanimity (17.2154-99; 732.12733.30) reveals that everyone-Boylan, Molly, Bloom himself-is partly to blame and partly innocent. The text enacts what Michael Ryan refers to as the "deconstruction of the presence of the observable event and of the authority of the single cause." This deconstruction "transforms that causal instance into a function within a larger differential text or tissue, a multiply determinate root system that constitutes the presence of the event without being reducible to the simple form of presence." 33 By the time we reach the unbounded, seemingly causeless chatter of "Penelope," we are far from "Nestor" and monocausality; and Molly's opening "Yes because" is only a faint, humorous recollection on the part of the text that Deasy ever said anything about women causing all the problems of history.

\section{MARRIAGE AS TELOS}

There is a puzzling moment in "Aeolus" when a strange voice breaks into the text, commenting, it seems, on the lighting of a match in the "false lull" before J. J. O'Molloy's recitation of a courtroom speech: "I have often thought since on looking back over that strange time that it was that small act, trivial in itself, that striking of that match, that determined the whole aftercourse of both our lives" (7.763-65; 140.6-9). It is difficult to situate these words in the mind of Stephen, even though he is capable of such elaborate playfulness; they seem to emerge from the mind of the text itself. In any case, this is a ludicrous example of monocausality in which "that small act ... that striking of that match" is the sole determinant of "the whole aftercourse of both our lives," precisely what Michael Ryan describes as "the presence of the observable event and the authority of the single cause."

But "that striking of that match" also refers to the match struck between Stephen and Bloom, the 'marriage' of the young man and the older man in what is the novel's chief, though most questionable, telos. Here, teleology and monocausality, inevitable goal and single cause, meet, for the "match" in question is both the event towards which the novel moves and the origin of "the whole aftercourse" of Stephen's and Bloom's lives. The stylistic intrusion in "Aeolus" has been identified as a parody of a passage in David Copperfield, but the significance of this parody has not been noticed. ${ }^{34}$ In chapter 10 of Dickens's novel, the wedding of Peggoty 
and Mr. Barkis takes place while David and Emily remain outside the church in the chaise (where David more or less proposes to her). The narrator David remarks, "I have often thought, since, what an odd, innocent, out-of-the-way kind of wedding it must have been! We got into the chaise again soon after dark, and drove cosily back, looking up at the stars, and talking about them." 35

Joyce's parody hints at a parallel between the Peggoty/Mr. Barkis union and that of Stephen and Bloom, and it is appropriate that this should be announced proleptically in "Aeolus," the episode in which Stephen and Bloom almost meet for the first time. ${ }^{36} \mathrm{We}$ should also note that there is a pun buried in "that striking of that match," for matches in this period frequently went by the tradename of "Vestas," and Vesta was the Roman goddess of the hearth, that is, of domestic life. (Stephen will presently refer to "Dublin vestals" in his Parable). Much later in the novel, at the end of "Eumaeus," Stephen and Bloom leave the cabman's shelter, observed by a streetsweeper who watches them "walk towards the railway bridge, to be married by Father Maher" (Joyce's italics; $16.1887-88 ; 665.20-21)$. As they continue, the driver "simply sat in his seat near the end of lower Gardiner street and looked after their lowbacked car" (could it be a chaise?). ${ }^{37}$ The 'wedding' itself takes place in "Ithaca" where "the keyless couple" (17.81; 668.17), once inside, drink Epps's cocoa together in what has been seen by many critics as a parody of the sacrament of the Eucharist. ${ }^{38}$ Surely Stephen and Bloom are only following the prescriptions of the Roman Catholic nuptial mass, which require the newly married couple to take communion together. And like the occupants of the marriage-chaise in David Copperfield, Stephen and Bloom do a good bit of "looking up at the stars" in "Ithaca."

But why figure the meeting of the two characters as a marriage? The Dickens parody should give us a clue. Ulysses, the novel to end novels, draws on, extends, and rebels against all the conventions of the genre, including marriage as the goal and denouement of plot. "If you think of a novel in the vague," remarked E. M. Forster, "you think of a love interest-of a man and woman who want to be united and perhaps succeed." ${ }^{39}$ Recently Joseph A. Boone has suggested that the "pivotal role accorded to marriage in realistic fiction corresponded, inevitably, to its increasingly central function in the rising middle-class cultures of eighteenth- and nineteenth-century England and America." Boone sees the fictional representation of "the Anglo-American myth of romantic wedlock" as one of the ways 
in which "social structures of belief are translated into narrative structures that encode and perpetuate such beliefs." 40

Joyce's "encoding" of this myth in Ulysses, however, is so ironic as to end by seriously questioning both social and narrative structures, leaving us to wonder whether marriage can serve any longer as the genre's cherished telos. From youth Joyce thoroughly distrusted the institution as an institution, and he did not actually marry Nora Barnacle, his lifelong companion, until 1931, more than two and a half decades after eloping with her to the Continent. At that time he remarked that "twenty-six years ago I did not want a clerk with a pen behind his ear or a priest in his nightshirt to interfere in my matrimonium." 11 His early socialist/anarchist aversion to marriage was so strong that in 1906, when he learned of Oliver Gogarty's marriage, he wrote his brother that "Gogarty would jump into the Liffey to save a man's life but he seems to have little hesitation in condemning generations to servitude." 42 Joyce was opposed to "tyrannies of all kinds," and he considered marriage to be one of these. The letters of this period consistently attack stories and novels with conventional love/marriage plots. Of The Vicar of Wakefield Joyce said that "when I arrived at page two of the narrative I saw the extreme putridity of the social system out of which Goldsmith had reared his flower. Is it possible that, after all, men of letters are no more than entertainers?" (Letters, 2:99). His own stories, which he was working on at this time, show love and marriage in a different light from that of Goldsmith: there are the failed elopement telos of "Eveline," the forced marriage of "The Boarding House," the domestic discord of "A Little Cloud," and the estrangement of Gretta and Gabriel in "The Dead." And in Stephen Hero Stephen loses Emma partly because he does not "believe that there was ever a moment of passion so fierce and energetic that it warranted a man in saying "I could love you for ever' to the adored object." 43 No one with opinions like these could have written a novel concluding, as Emma does, with the assurance that "the predictions of the small band of true friends who witnessed the ceremony, were fully answered in the perfect happiness of the union." 44

There are subtle reminders throughout Ulysses of the kind of novel it does not intend to be. In "Wandering Rocks," Father Conmee, who "walked and moved in times of yore" and who considers writing a novel about adulterous nobility, projects himself into a very "novelistic" scene: "And the hands of a bride and of a bride- 
groom, noble to noble, were impalmed by Don John Conmee" $(10.177-78 ; 223.42-224.2) .{ }^{45}$ We find the same image of impalming in the story Bloom reads on the jakes about a man who "won the laughing witch who now." Bloom observes, "Begins and ends morally. Hand in hand. Smart" (Joyce's italics; 4.514-15; 69.13-14). The name of the story is Matcham's Masterstroke, a modest scrambling of "that striking of that match." Though Bloom considers the story "smart," he also thinks, "Life might be so. It did not move or touch him but it was something quick and neat" (4.511-12; 69.910). Bloom himself might "invent a story for some proverb" (4.518$19 ; 69.18-19)$, somewhat in the Beaufoy vein. But a different aesthetic idea occurs to him moments later when he recalls hearing Ponchielli's "Dance of the Hours": "Evening hours, girls in grey gauze. Night hours then: black with daggers and eyemasks. Poetical idea: pink, then golden, then grey, then black. Still, true to life also. Day: then the night" $(4.534-36 ; 69.38-41)$. This idea is diametrically different from Beaufoy's plot. Bloom's story would faithfully record, in a non-teleological fashion, the simple, poignant passage of time, "Day: then the night." It would present reality paratactically rather than hypotactically, in subordination to a point. It would be "poetical" but "true to life also": no description of Ulysses could be apter or more succinct. ${ }^{46}$

The marriage motif returns in "Circe." Stephen asks Lynch for a cigarette, "strikes a match and proceeds to light the cigarette with enigmatic melancholy" (Joyce's italics). Meanwhile he mutters, "And so Georgina Johnson is dead and married... Married." (15.3619-23; 559.20-25). As Stephen "brings the match near his eye" (Joyce's italics) and draws it away, he learns that "it was a commercial traveller married her and took her away with him" (my italics; $15.3634 ; 560.9-10$ ). Once again the text is alluding to the 'match' between Stephen and Bloom, the engagement that will be formalized at the end of the next episode, "Eumaeus."

Stanislaus Joyce wrote of his brother that "he came to consider a well-ordered plot in a novel or story as a meretricious literary interest, like the story in a tableau de genre." ${ }^{7}$ Some of the novels mentioned in the text of Ulysses are similarly skeptical of traditional marital developments and well-made plots, and their heterodoxy provides an implicit commentary on the theme of marriage in Joyce's novel. Boylan's secretary, Miss Dunne, has been reading Wilkie Collins's The Woman in White, but she finds it unsatisfactory: "Too much mystery business in it. Is he in love with that one, 
Marion? Change it and get another by Mary Cecil Haye" (10.371$72 ; 229.14-15)$. Mary Cecil Haye was a popular sentimental novelist of the type Gerty MacDowell would probably have read. Collins's intricate plot would put off anyone who expected clearcut intrigues and happy resolutions. Joseph A. Boone says of The Woman in White that it is one of the midcentury Victorian novels that "begin to complicate this formulation by introducing darker portraits of marital antagonism that are resolved only by death and a more felicitous second marriage for the long-suffering wife." 48 Molly seems to be having similar difficulties with Ruby: the Pride of the Ring, for she complains to Bloom, "There's nothing smutty in it. Is she in love with the first fellow all the time?" $(4.355-56$; 64.36-37). Molly prefers a more obvious plot line and love element, and asks Bloom to get her "another of Paul de Kock's."

These novels within Joyce's novel are synecdoches for the generally problematic status of marriage in Ulysses, a work that begins with a strained marriage and ends with the hero reconciling himself to his wife's infidelity. The 'marriage' between Stephen and Bloom is equally questionable, considering how many misunderstandings they encounter in their social intercourse. But there is a sense in which the Bloom/Stephen marriage, like all the symbols of the late episodes, gestures towards a potential that cannot be realized or fully expressed in the timeframe of Ulysses. In her discussion of the literary treatment of marriage, Evelyn J. Hinz distinguishes between "wedlock," which is the conventional bourgeois idea of marriage, and "hierogamy." The latter is "the sacred marriage, and the prototype of this is the union of the earth and sky." A good example is the "hierogamous union" of Catherine and Heathcliff in Wuthering Heights, while "the legal marriage" of Catherine and Linton is merely "wedlock." 49 Bloom's marriage to Molly and his relationship with Stephen, though perplexed on the naturalistic level, could be seen in "hierogamous" terms, as "sacred marriages," potentialities which the novel takes into account as such but does not actualize as teloi. This would partly account for the association of Molly with Gea-Tellus and for the stellar and lunar imagery that clusters around Stephen, Bloom, and Molly in "Ithaca." As Stephen and Bloom urinate in the garden, looking up at Molly's lighted window, "a star precipitated with great apparent velocity across the firmament from Vega in the Lyre above the zenith beyond the stargroup of the Tress of Berenice towards the zodiacal sign of Leo" (17.1211-13; 703.24-27). This accords with Hinz's observation that 
"hierogamous unions must take place in the open or in an elemental setting because their object is to evoke the primordial marriage of the elements." 50 Such unions, Hinz says, do not take place in public buildings, which "signify profane time and social values." The fact that Bloom and Stephen are betrothed, as it were, in the cabman's shelter and go off "to be married by Father Maher" only points up once again Joyce's "two-plane" balancing of the mundane and the mythic. The potential and the actual exist side by side, and neither is allowed to preponderate.

Since marriage is a nearly universally accepted telos, it is also a common source for teleological metaphors. Quite deliberately, Jacques Derrida uses a marital figure to characterize Rousset's teleological/structuralist reading of Corneille (which sees Polyeucte as bringing a certain aesthetic pattern to perfect completion): "The structure thus was a receptive one, waiting, like a girl in love, ready for its future meaning to marry and fecundate it." Derrida continues: "Why then, once more, this geometer's privilege? Assuming ... that beauty lets itself be espoused or exhausted by the geometer, is he not ... forced to commit an act of violence?" (WD, 18, 20). Derrida would say that the violence that occurs when form and meaning are brought together is also paradoxically a repose, an end to formal tension and the struggle of meaning, a silencing of force and becoming.

We may compare what E. M. Forster says of the conventional novel: "Love, like death, is congenial to a novelist because it ends a book conveniently. He can make it a permanency, and his readers easily acquiesce, because one of the illusions attached to love is that it will be permanent. Not has been-will be."51 It is interesting that Jacob Burckhardt, objecting to "reading into" history in order to establish closures and teleologies, attacks the facile notion that "equates changelessness with happiness. From its childish standpoint it may strive to hold fast to the image of a permanent, joyous well-being." Burckhardt goes on to say that the "end of the Odyssey is so much nearer the truth. The trials of him who has suffered so much are to continue, and he must at once set out on a grievous pilgrimage."52

This is the sense we are left with at the end of Ulysses. Though the novel jokes about Stephen and Bloom going off to be married by Father Maher and taking nuptial communion together, in reality the later episodes hold off resolution and closure by putting styles and irony between the bride and the bridegroom. What Derrida 
says of the same/other dialectic in "Force and Signification" uncannily applies to Bloom and Stephen in "Eumaeus" and "Ithaca": "For the fraternal other is not first in the peace of what is called intersubjectivity, but in the work and peril of inter-rogation; the other is not certain within the peace of the response in which two affirmations espouse each other, but is called up in the night by the excavating work of interrogation" (WD, 29-30; Derrida's italics). Bloom and Stephen are not "impalmed" at the end of the novel, for "the excavating work of interrogation" in "Ithaca" sees to it that all their incompatibilities-which signal their mutual "otherness"are respected and preserved.

Bloom himself hits upon a fine anti-teleological conceit when, getting into bed next to Molly, he reflects

that each one who enters imagines himself to be the first to enter whereas he is always the last term of a preceding series even if the first term of a succeeding one, each imagining himself to be first, last, only and alone whereas he is neither first nor last nor only nor alone in a series originating in and repeated to infinity. (17.2127-31; 731.18-23)

Here Bloom, the realistic cuckold, deflates the patriarchal vanity that begets structures and teleologies and regards the female as convenient "matter" or meaning to which it might wed its "form." As Bloom drifts off to sleep, the last masculine voice in the novel mumbles variations on "Sinbad the Sailor," suggesting that, as in The Thousand and One Nights, this is but one narrative development among many, not the first or last or only or alone, just one in a series that can boast of no telos. Scheherezade stays alive simply by generating tales that will keep the Sultan Shahriar, who like Deasy is convinced of the faithlessness of women, from murdering her; and their marriage is sustained, not by the usual telos of permanency, but by a witty deferral of death through the agency of concatenated fictions. The reference to Sinbad in Ulysses hints at Joyce's similar flouting of traditional fictive consummations, for the progress of styles and episodes postpones narrative closure and death as cleverly as Scheherezade's yarn-spinning. (Finnegans Wake likewise alludes in its final pages to "a thousand of years of the nights." $)^{53}$ In the incoherence at the end of "Ithaca" the novel is turned over to another Scheherezade who, in her sheer unconcern for diurnal structures and formalities, will conclude this work by opening it irrevocably, as Gérard Genette says of Proust's Re- 
cherche, "to its sense of unfulfillment, to the shiver of the indefi-
nite, to the breath of the imperfect." 54 University of Tulsa

\section{NOTES}

${ }^{1}$ Roland Barthes, Writing Degree Zero, trans. Annette Lavers and Colin Smith (New York: Hill and Wang, 1984), 31.

${ }^{2}$ Barthes, 31.

${ }^{3}$ Barthes, 32-33.

${ }^{4}$ From an interview with Jean-Louis Houdebine and Guy Scarpetta, in Jacques Derrida, Positions, trans. Alan Bass (Chicago: Univ. of Chicago Press, 1982), 56.

${ }^{5}$ James Joyce, The Critical Writings, ed. Ellsworth Mason and Richard Ellmann (New York: The Viking Press, 1965), 81. Hereafter cited in the text as $C W$.

${ }^{6}$ All citations from Ulysses are followed by two sets of page references: the first is to the Garland edition (New York, 1984), the text of which is now available in Penguin and Random House editions; and the second is to the Random House text (New York, 1961). Until the Garland edition, "All human history" read "All history." The restoration derives from the Rosenbach MS.

${ }^{7}$ Compare these "idols that corrupt .. ". from without and within" with Stephen's thoughts as he hears the powerhouse in "Wandering Rocks": "Throb always without you and the throb always within. Your heart you sing of. I between them. Where? Between two roaring worlds where they swirl, I. Shatter them, one and both. But stun myself too in the blow" (10.822-25; 242.13-16). In "Circe" Stephen will try, Siegfried-like, to shatter the historical constraints placed on him and will indeed stun himself in the blow, as he predicts here.

${ }^{8}$ Ernst Cassirer, The Myth of the State (New Haven: Yale Univ. Press, 1946), 262. To call Deasy's idea of history "Hegelian" can be little more than convenient notation, however, since many theorists would regard Cassirer's statement as a simplification comparable to the "efficiency" of teleology itself. Georg Lukács, for instance, sees the post-Hegelian "ideology of progress" as a vulgarization of Hegel's "idea of the contradictory character of progress" (The Historical Novel, trans. Hannah and Stanley Mitchell [Lincoln: Univ. of Nebraska Press, 1983], 174). And Fredric Jameson prefers the Hegelian model to other metaphors for history because "it is distinguished by that ultimate and inevitable, structurally inherent movement toward its own dissolution, in which it projects the Marxist model out of itself as its own concrete realization and fulfillment" (Marxism and Form: Twentieth-Century Dialectical Theories of Literature [Princeton: Princeton Univ. Press, 1974], 326).

${ }^{9}$ Rudolf Haym, Hegel und seine Zeit (1857), quoted in Cassirer, 251. 54.

${ }^{10}$ R. G. Collingwood, The Idea of History (1946; Oxford: Clarendon Press, 1949),

11 Compare Michel Foucault on "progressivist" history: "I don't say that humanity doesn't progress. I say that it is a bad method to pose the problem as: 'How is it that we have progressed?'. The problem is: how do things happen?" ("Prison Talk," in Power/Knowledge: Selected Interviews and Other Writings: 1972-1977, ed. Colin Gordon [New York: Pantheon Books, 1980], 50). Colin MacCabe suggests that this shout in the street is "the undifferentiated sound from which we fabricate meaning. It is by plunging into this sound that we can unmake the meanings imposed on us and awake from the nightmare of history into the dream of language" ("An introduction to Finnegans Wake," in James Joyce: New Perspectives, ed. Colin MacCabe [Bloomington: Indiana Univ. Press; Sussex: The Harvester Press, 1982], 35). For an interesting discussion of Ulysses, politics, and history (in part, teleological history), see G. J. Watson, "The Politics of Ulysses," in Joyce's "Ulysses": The Larger Per- 
spective, ed. Robert D. Newman and Weldon Thornton (Newark: Univ. of Delaware Press, 1987), 39-58. Ulrich Schneider also touches on providentialist history in " "An actuality of the possible': Reflections on the Theme of History in 'Nestor,' " in International Perspectives on James Joyce, ed. Gottlieb Gaiser (Troy, N.Y.: Whitston, 1986), 44-58.

${ }^{12}$ From Karl Popper, The Open Society and Its Enemies, reprinted in The Philosophy of History in Our Time, ed. Hans Meyerhoff, (Garden City, N.J., 1959) 308.

${ }^{13}$ Popper, 307.

${ }^{14}$ Eugene Webb observes that in Ulysses history "is moving toward the manifestation of God, but not Mr. Deasy's God-rather the book's immanent God, 'the obscure soul of the world.' And the vehicle of this manifestation is already wandering the streets, as they talk, on his way to a bath house" (The Dark Dove: The Sacred and Secular in Modern Literature [Seattle: Univ. of Washington Press, 1975], 130 31). I agree with the substance of these remarks, though I feel the language is incompatible with the anti-teleological impetus behind the story of Bloom.

${ }^{15}$ Joseph Conrad, The Mirror of the Sea (New York: Harper and Brothers, 1906), 259. Conrad uses this phrase to describe his first sea-voyage. This work abounds in references to the Odyssey and frequently alludes to the notion of a modern Ulysses. For example, describing a fellow sailor, Dominic Cervoni, Conrad says: "Astute and ruthless, he could have rivalled in resource the unfortunate son of Laertes and Anticlea.... A one-eyed giant would have had not the ghost of a chance against Dominic Cervoni, of Corsica, not Ithaca" (275). It is worth noting that The Mirror of the Sea appeared in the same year (1906) that Joyce conceived Ulysses as a short story. Though this title is not in Joyce's Trieste library, several other works by Conrad from this period are.

${ }^{16}$ Kenneth Burke, A Grammar of Motives (1945; Berkeley: Univ. of California Press, 1969), 231-32. Compare Derrida's claim that the teleology present in the "ultrastructuralist" method contradicts "the most precious and original intention of structuralism." "To be a structuralist," he says, "is first to concentrate on the organization of meaning, on the autonomy and idiosyncratic balance, the completion of each moment, each form" (Writing and Difference, trans. Alan Bass [Chicago: Univ. of Chicago Press, 1978], 26); hereafter cited as WD in the text.

${ }^{17}$ Note how "possibilities of the possible as possible" is a theosophical thinning of Stephen's formula for history in "Nestor": "an actuality of the possible as possible" (2.67; $25.35-36)$.

${ }_{18}$ T. S. Eliot, The Waste Land, in Collected Poems, 1909-1962 (San Diego: Harcourt Brace Jovanovich, 1970), 55.

${ }^{19}$ Joyce seems to have been aware of the tension between providentialist progression and mere succession as early as the first version of his story "The Sisters" (his first published piece of fiction). The story begins, "Three nights in succession I had found myself in Great-Britain street at that hour, as if by Providence. Three nights also I had raised my eyes to that lighted square of window and speculated. I seemed to understand that it would occur at night. But in spite of Providence that had led my feet and in spite of the reverent curiosity of my eyes, I had discovered nothing" (The Irish Homestead, August 13, 1904, 676). When Joyce revised the story two years late he completely overhauled the opening and dropped the references to Providence. L. J. Morrissey argues that Joyce's changes represent a move towards a "writerly" text and away from nineteenth-century narrative modes ("Joyce's Revision of 'The Sisters': From Epicleti to Modern Fiction," James Joyce Quarterly 24 [Fall 1986]: 38).

${ }^{20}$ Karen Lawrence claims that the "mushrooming sentences" in "Wandering Rocks" "undermine any sense of telos in the writing" (The Odyssey of Style in "Ulysses" [Princeton: Princeton Univ. Press, 1981], 87).

${ }^{21}$ Helène Cixous sees Stephen's riddle as typical of disorienting strategies in Ulysses which disrupt received histories, authority, certitude, and notions of male 
potency ("Joyce: The (r)use of writing," in Post-Structuralist Joyce: Essays from the French, ed. Derek Attridge and Daniel Ferrer [Cambridge: Cambridge Univ. Press, 1984], 19-21).

${ }^{22}$ Fritz Senn, "Righting Ulysses," in MacCabe (note 11), 24. Phillip Herring, "Structure and Meaning in Joyce's "The Sisters," in The Seventh of "Joyce," ed. Bernard Benstock (Bloomington: Indiana Univ. Press; Sussex: The Harvester Press, 1982), 138.

${ }^{23}$ See Lawrence (note 20 ).

${ }^{24}$ John Paul Riquelme, Teller and Tale in Joyce's Fiction: Oscillating Perspectives (Baltimore: Johns Hopkins Univ. Press, 1983), 228-29.

${ }^{25}$ In a recent essay on Joyce's A Portrait of the Artist as a Young Man, Michael Levenson has shown that the diary entries concluding the work jar against the whole tradition of the novel of growth: "It should be evident that the conventions of the Bildungsroman cannot be assimilated to the pattern of serial repetition. The Bildungsroman presupposes some principle of development, which in turn presupposes some concept of an end. .. . To our question, What is the shape of a life? the upward curve of bildung suggests one answer, the unswerving line of repetitions another" ("Stephen's Diary in Joyce's Portrait-The Shape of Life," ELH 52 [1985]: 1021). I propose that the stylistic shift in Ulysses to Molly's rambling, non-narratorial voice is analogous to the generic shift to the diary in A Portrait, and has the same effect of disrupting closure and conclusion.

${ }^{26}$ Riquelme (note 24), 228.

${ }^{27}$ Marc Bloch's definition of historical "origin" is useful here: "In popular usage, an origin is a beginning which explains. Worse still, a beginning which is a complete explanation. There lies the ambiguity, and there the danger!" (The Historian's Craft, trans. Peter Putnam [New York: Vintage Books, 1953], 30).

${ }^{28}$ Michael Ryan, Marxism and Deconstruction: A Critical Articulation (Baltimore: Johns Hopkins Univ. Press, 1982), 40.

${ }^{29}$ See Burke's definition of "efficiency" in Attitudes Toward History (1937; Berkeley and Los Angeles: Univ. of California Press, 1984), 248-52.

${ }^{30}$ The Citizen's opinions about Jews and women are almost identical with Deasy's: "A dishonoured wife, says the citizen, that's what the cause of all our misfortunes" (12.1163-64; 324.11-12).

${ }^{31}$ W. J. McCormack writes, "Throughout Ulysses Stephen is preoccupied with the larger implications of his mother's death, for his nightmare is located at the scene of her death and his (non-)involvement in it" ("Nightmares of History," in James Joyce and Modern Literature, ed. W. J. McCormack and Alistair Stead (London: Routledge and Kegan Paul, 1982), 91). McCormack contends that the ghost of May Dedalus represents Stephen's guilt as incipient modern artist for his nonengagement with history.

${ }^{32}$ The figure of Old Gummy Granny in "Circe" is a burlesque on the positing of woman and history as monocauses. As the traditional "Old Woman," she represents Ireland, and her ludicrous urging of Stephen to dispatch Private Carr-"Remove him, acushla" (15.4737; 600.16-17)-mocks Deasy's notion that women should bear, along with everything else, the responsibility for history's problems.

${ }^{33}$ Ryan (note 28 ), 40-41.

${ }^{34}$ See Don Gifford and Robert J. Seidman, Notes for Joyce: An Annotation of James Joyce's “Ulysses” (New York: E. P. Dutton, 1974), 115.

${ }^{35}$ Charles Dickens, David Copperfield (Toronto: Bantam Books, 1981), 136.

${ }^{36}$ Other parallels to the Bloom/Stephen meeting are worth noting: Peggoty is in mourning, as is David, for the death of David's mother. When the engaged couple set out in the chaise, we are told that "Peggoty was dressed as usual, in her neat and quiet mourning; but Mr. Barkis bloomed in a new blue coat" (134). It is also interesting at this point in the novel David is much depressed by his mother's recent death: "I was still giddy with the shock of my mother's death, and in a kind of 
stunned state as to all tributary things." He fears he will grow up "to be a shabby moody man, lounging an idle life away" (124). Chapter 10 is entitled "I Become Neglected, and Am Provided For," which could stand as a rough summary of Stephen and Bloom's relationship from "Oxen of the Sun" on.

${ }^{37}$ The lines come from a popular song, "The Low-Backed Car" (Gifford and Seidman, 277, 459). In one version, by Samuel Lover, the girl's name is Peggy.

${ }^{38}$ William York Tindall, A Reader's Guide to James Joyce (New York: The Noonday Press, 1961), 222, observes that Stephen and Bloom's "sitting down together in the kitchen celebrates communion or the sacramental sealing of togetherness." That last phrase flirts with the idea of matrimony, but Tindall is more interested in the theological (Father/Son) implications of the sharing of Epps's cocoa (a "massproduct").

${ }^{39}$ E. M. Forster, Aspects of the Novel (New York: Harcourt Brace, 1927), 85.

${ }^{40}$ Joseph A. Boone, "Modernist Maneuverings in the Marriage Plot: Breaking Ideologies of Gender and Genre in James's The Golden Bowl," PMLA 101 (1986): 374,375 .

${ }^{41}$ Quoted in Richard Ellmann, James Joyce (Oxford: Oxford Univ. Press, 1983), 637.

${ }^{42}$ James Joyce, Letters, ed. Richard Ellmann (New York: The Viking Press, 1966), 2:148.

${ }^{43}$ James Joyce, Stephen Hero (1944; New York: New Directions, 1963), 201. Stephen's lengthy discussion of marriage with Lynch (200-203) reveals the range of objections Joyce had formed to the institution.

${ }^{44}$ The Novels of Jane Austen, ed. R. W. Chapman (London: Oxford Univ. Press, 1952), 4:484.

45 The marriage/teleology motif is also present in Father Conmee's musings four lines earlier about the Pauline rationalization for marriage: "Father Conmee thought of the tyrannous incontinence, needed however for man's race on earth, and of the ways of God which were not our ways" (10.171-3; 223.36-38). The phrase distinctly recalls Deasy's "The ways of the Creator are not our ways. ... All human history moves towards one great goal, the manifestation of God" $(2.380-81 ; 34.26-28)$.

${ }^{46}$ Bloom frequently contemplates scenes or ideas that seem to encapsulate perfectly the treatment of time and plot in Ulysses. Earlier in "Calypso" he imagines journeying "round in front of the sun, steal a day's march on him." His travels would take him through oriental lands, and finally: "A shiver of the trees, signal, the evening wind. I pass on. Fading golden sky. A mother watches me from her doorway. ... Listen. A girl playing one of those instruments what do you call them: dulcimers. I pass" (4.93-98; 57.26-32). Though Bloom thinks, "Probably not a bit like it really. Kind of stuff you read" $(4.99 ; 57.33)$, we know that it is the kind of stuff you are likely to read in Ulysses or a Dubliners story, where events are presented randomly rather than in a conventionally developmental fashion. Compare also Bloom's thoughts in "Lestrygonians": "Things go on same, day after day: squads of police marching out, back: trams in, out" (8.477-78; 164.17-19).

${ }^{47}$ Stanislaus Joyce, My Brother's Keeper, (New York: The Viking Press, 1969), 92.

48 Boone (note 40), 376.

49 Evelyn J. Hinz, "Hierogamy versus Wedlock: Types of Marriage Plots and Their Relationship to Genres of Prose Fiction." PMLA 91 (1976): 905-6.

${ }^{50}$ Hinz, 909.

51 Forster (note 39), 86.

52 Jacob Burckhardt, "On Fortune and Misfortune in History," reprinted in Meyerhoff (note 12), 281, 282.

${ }^{53}$ James Joyce, Finnegans Wake (New York: The Viking Press, 1959), 627.

${ }^{54}$ Gérard Genette, Narrative Discourse: An Essay in Method, trans. Jane E. Lewin (Ithaca: Cornell Univ. Press, 1983), 267. 